\begin{tabular}{c|c|c}
\hline JURNAL PENELITIAN FARMASI HERBAL & VOL. 1 NO. 2 & $\begin{array}{c}\text { EDITION: NOVEMBER 2018 } \\
\text { APRIL 2019 }\end{array}$ \\
\hline & http://ejournal.delihusada.ac.id/index.php/JPFH & \\
\hline RECEIVED: 17 FEBRUARI 2019 & REVISED: 20 MARET 2019 & ACCEPTED: 26 APRIL 2019 \\
\cline { 1 - 2 }
\end{tabular}

\title{
DETERMINATION OF MINERAL Ca CONTENT IN SEVERAL KINDS OF FRESH FOOD AND PROCESSED PRODUCTS AS SWEETMEAT
}

\author{
Ahmad Syukur Hasibuan, Fahma Shufyani, Rinaldo \\ Institut Kesehatan Medistra Lubuk Pakam, Jl. Sudirman No.38 Lubuk Pakam \\ e-mail : syukurhasibuan18@gmail.com
}

\begin{abstract}
The basic thing that differentiate both is how to make it, lasting power, and design products. This study aims to determine the level of calcium in the sample of fresh guava, ginger, and nutmeg, and to investigate the mineral calcium levels in samples of fresh and processed products as wet sweetmeat and dry sweetmeat. Each sample must first be destructed by dry destruction, then the mineral assay performed with quantitative assay atomic absorption spectrophotometry (AAS) using a gas burner nitrous oxide-acetylene at a wavelength of $422.7 \mathrm{~nm}$. The advantage of this method is to have a high sensitivity (limit of detection of less than $1 \mathrm{ppm}$ ), and the implementation is relatively simple. Calcium levels in samples of fresh guava, ginger and nutmeg in a row each each sample as follows (7.7105 \pm 0.1224$) \mathrm{mg} / 100 \mathrm{~g},(14.5232 \pm 0.117) \mathrm{mg} / 100 \mathrm{~g}$ and $(38,8834 \pm$ $0.6996) \mathrm{mg} / 100 \mathrm{~g}$. In the wet sweetmeat guava, ginger and nutmeg for (13.7787 \pm $0.4123) \mathrm{mg} / 100 \mathrm{~g},(22.8345 \pm 0.8247) \mathrm{mg} / 100 \mathrm{~g}$ and $(0.2284 \pm 0.3759) \mathrm{mg} / 100 \mathrm{~g}$. While on dry sweetmeat guava, ginger and nutmeg for $(160.9401 \pm 0.4223) \mathrm{mg} / 100 \mathrm{~g}$, $(176.0465 \pm 1.0458) \mathrm{mg} / 100 \mathrm{~g}$ and $(120.4426 \pm 0.7932) \mathrm{mg} / 100 \mathrm{~g}$. Levels of calcium contained in a sample of fresh guava, ginger and nutmeg and sweetmeat processed as wet and dry sweetmeat has different levels
\end{abstract}

Keywords: Sweetmeat, Calcium, Atomic Absorption, Spectrophotometer

\section{PENDAhUlUAN}

Masyarakat terus mencari cara untuk mengubah cita rasa buah masam menjadi lebih enak atau manis, serta dapat dinikmati setiap saat. Salah satu caranya adalah dengan mengolahnya menjadi manisan. Selain untuk memenuhi keinginan konsumen, manisan dibuat atas dasar pertimbangan sifat fisiologis buah. Meskipun telah dipanen atau lepas dari pohonnya, proses-proses fisiologis seperti respirasi dan transpirasi dalam buah tetap terjadi sehingga buah tidak tahan lama atau cepat busuk. Bentuk manisan bisa mempertahankan tekstur dan warna buah, serta mengubah cita rasa buah menjadi lebih baik (Fatah dan Bachtiar, 2004).Manisan buah adalah produk olahan buah dengan penambahan gula, sitrat, dan aroma tertentu berupa esens. Saat ini, menisan buah makin banyak menarik minat masyarakat baik untuk mengkonsumsinya atau untuk dijadikan sebagai industri rumah tangga. Terbukti, hampir di setiap supermarket atau toko-toko yang menjual makanan menjajakan aneka jenis manisan buah yang dibarengi pula dengan banyaknya masyarakat yang membeli manisan tersebut (Ayu dan Rini, 2012).

Buah umumnya lebih banyak mengandung vitamin dari kelompok B kompleks dan vitamin $C$. Disamping itu juga mengandung berbagai jenis mineral, seperti kalium $(\mathrm{K})$, kalsium (Ca), natrium ( $\mathrm{Na})$, dan zat besi ( $\mathrm{Fe})$. Karena kandungannya ini, masyarakat menjadikan buah sebagai bagian penting dari makanan sehari-harinya (Fatah dan Bachtiar, 2004). Peranan kalsium dalam tubuh pada umumnya dapat dibagi dua, yaitu membantu membentuk tulang dan gigi dan mengukur proses biologis dalam tubuh.

Pada proses pembuatan manisan, buah yang telah dikupas dan dipotong, direndam dalam 


\begin{tabular}{c|c|c}
\hline JURNAL PENELITIAN FARMASI HERBAL & VOL. 1 NO. 2 & $\begin{array}{c}\text { EDITION: NOVEMBER 2018 - } \\
\text { APRIL 2019 }\end{array}$ \\
\hline & http://ejournal.delihusada.ac.id/index.php/JPFH & \\
\cline { 2 - 2 } RECEIVED: 17 FEBRUARI 2019 & ACCEPTED: 26 APRIL 2019 \\
\hline
\end{tabular}

air kapur. Buah tersebut dibiarkan dalam rendaman larutan air kapur selama beberapa jam untuk selanjutnya dibilas dan dicuci bersih (Ayu dan Rini, 2012).

Kapur digunakan untuk memberikan bentuk tekstur buah yang diolah menjadi olahan manisan sehingga terasa lebih gurih dan renyah. Perubahan ini disebabkan adanya senyawa kalsium dalam kapur yang berpenetrasi ke dalam jaringan buah.

Spektrofotometri serapan atom digunakan untuk analisis kuantitatif senyawa logam dalam jumlah sekelumit (trace) dan sangat kelumit (ultratrace). Cara analisis ini memberikan kadar total unsur logam dalam suatu sampel dan tidak tergantung pada bentuk molekul dari logam dalam sampel tersebut. Cara ini cocok untuk analisis kelumit logam karena mempunyai kepekaan yang tinggi (batas deteksi kurang dari 1 ppm), pelaksanaannya relatif sederhana dan interferensinya sedikit (Rohman, 2007).

Berdasarkan uraian di atas, penulis tertarik untuk meneliti kadar kalsium untuk masingmasing sampel dalam keadaan segar dan olahannya sebagai manisan basah dan manisan kering dengan metode spektrofotometri serapan atom. Karena berdasarkan cara pengolahannya sesuai uraian di atas akan menghasilkan kadar kalsium yang berbeda-beda untuk setiap sampel.

\section{METODE}

Alat yang digunakan pada penelitian ini adalah Spektrofotometer Serapan Atom (Hitachi Zeeman-2000) dengan nyala udaraasetilen lengkap dengan lampu katoda $\mathrm{Ca}$, hot plate (BOECO Germany), krus porselin, neraca analitik (AND GF-200), tanur (Stnart), kertas saring Whatman No.42, dan alat - alat gelas (Pyrex dan Oberoi).

\section{Bahan}

Bahan-bahan yang digunakan dalam penelitian ini berkualitas pro analisis keluaran E. Merck yaitu asam nitrat $65 \% \mathrm{v} / \mathrm{v}$, larutan baku kalsium $1000 \mu \mathrm{g} / \mathrm{mL}$, kecuali akua demineralisata (Laboratorium Penelitian Fakultas Farmasi USU).

\section{Pengambilan Sampel}

Metode pengambilan sampel dilakukan dengan cara sampling purposif yang dikenal juga sebagai sampling pertimbangan dimana sampel ditentukan atas pertimbangan bahwa populasi sampel adalah homogen dan sampel yang diambil mempunyai karakteristik yang sama dengan sampel yang tidak diambil (Sudjana, 2005).

\section{Penyiapan Sampel}

Sampel segar jambu biji, jahe, dan pala dan olahannya dalam bentuk manisan basah dan manisan kering masing-masing ditimbang sebanyak $20 \mathrm{~g}$.

\section{Proses Destruksi}

Sampel yang telah dipotong kecil-kecil masing-masing ditimbang sebanyak 20 gram, dimasukkan ke dalam krus porselen, dilakukan pengaranganpada hot plate selama 6 jam lalu diabukan di tanur dengan temperatur awal $100^{\circ} \mathrm{C}$ dan perlahan-lahan dinaikkan menjadi $500^{\circ} \mathrm{C}$ dengan interval $25^{\circ} \mathrm{C}$ setiap 5 menit. Pengabuan dilakukan selama 40 jam dan dibiarkan dingin lalu dipindahkan ke desikator. Abu diteteskan 10 tetes akua demineralisata dan ditambahkan 5 $\mathrm{ml} \mathrm{HNO}_{3}$ (1:1). Kemudian kelebihan $\mathrm{HNO}_{3}$ diuapkan pada hot plate dengan suhu $100-$ $120^{\circ} \mathrm{C}$ sampai kering. Krus porselen dimasukkan ke dalam tanur dan diabukan selama 1 jam dengan suhu $500^{\circ} \mathrm{C}$, kemudian didinginkan (Helrich, 1990 dengan pengubahan).

\section{Pembuatan Kurva Kalibrasi Kalsium}

Larutan baku kalsium $(1000 \mu \mathrm{g} / \mathrm{ml})$ dipipet sebanyak $1 \mathrm{ml}$, dimasukkan ke dalam labu tentukur $50 \mathrm{ml}$ dan dicukupkan hingga garis tanda dengan akua demineralisata (konsentrasi $20 \mu \mathrm{g} / \mathrm{ml}$ ).

Larutan untuk kurva kalibrasi kalsium dibuat dengan memipet $(2,5 ; 5,0 ; 7,5 ; 10,0$; dan $12,5) \mathrm{ml}$ larutan baku $20 \mu \mathrm{g} / \mathrm{ml}$, masingmasing dimasukkan ke dalam labu tentukur 
$25 \mathrm{ml}$ dan dicukupkan hingga garis tanda dengan akua demineralisata (larutan ini mengandung $(2,0 ; 4,0 ; 6,0 ; 8,0$; dan 10,0$)$ $\mu \mathrm{g} / \mathrm{ml})$.

\section{Penetapan Kadar Kalsium Pada Sampel}

Masing-masing sampel diukur absorbansinya dengan menggunakan spektrofotometer serapan atom pada panjang gelombang $422,7 \mathrm{~nm}$ dengan nyala udara-asetilen. Nilai absorbansi yang diperoleh harus berada dalam rentang kurva kalibrasi larutan baku kalsium. Konsentrasi kalsium dalam sampel ditentukan berdasarkan persamaan garis regresi dari kurva kalibrasi.

\section{Perhitungan Kadar Natrium, Kalsium dan Tembaga Pada Sampel}

Kadar kalsium, natrium dan tembaga dalam sampel dapat dihitung dengan cara sebagai berikut:

$\operatorname{Kadar}(\mu \mathrm{g} / \mathrm{g})=\frac{\mathrm{C} \times \mathrm{V} \times \mathrm{Fp}}{\mathrm{W}}$

Keterangan:

$\mathrm{C}=$ Konsentrasi logam dalam larutan sampel $(\mu \mathrm{g} / \mathrm{mL})$

$\mathrm{V}=$ Volume larutan sampel $(\mathrm{mL})$

$\mathrm{Fp}=$ Faktor pengenceran

$\mathrm{W}=$ Berat sampel $(\mathrm{g})$

\section{Analisis Statistik}

Menurut (Sudjana, 2005) kalsium, natrium dan tembaga yang diperoleh dari hasil pengukuran masing-masing larutan sampel diuji secara statistik dengan cara menghitung standar deviasi menggunakan rumus sebagai berikut:

$S D=\sqrt{\frac{\sum(\mathrm{Xi}-\overline{\mathrm{X}})^{2}}{\mathrm{n}-1}}$

Keterangan:

$\mathrm{Xi}=$ Kadar sampel

$\bar{X}=$ Kadar rata-rata sampel

$\mathrm{n}$ = Jumlah pengulangan
Kadar yang diperoleh dari hasil pengukuran masing-masing ke enam larutan sampel, diuji secara statistik dengan uji t. Untuk mengetahui data ditolak atau diterima dilakukan dengan uji $t$ yang dapat dihitung dengan rumus:

$t_{\text {hitung }}=\frac{|X i-\bar{X}|}{S D / \sqrt{n}}$

Hasil pengujian atau nilai $t_{\text {hitung }}$ yang diperoleh ditinjau terhadap tabel distribusi $t$, apabila $t_{\text {hitung }}<t_{\text {tabel }}$ maka data tersebut diterima. Untuk menentukan kadar suatu zat di dalam sampel dengan interval kepercayaan 95\%, $a=0,05, d k=n-1$, dapat digunakan rumus:

$\mu=\bar{X} \pm t_{\left(\frac{1}{2} \alpha, d k\right)} S D / \sqrt{n}$

Keterangan:

$\mu=$ kadar logam

$\bar{X}=$ kadar rata-rata sampel

$\mathrm{t}=$ harga $\mathrm{t}$ tabel sesuai dengan $\mathrm{dk}=\mathrm{n}-1$

$a=$ tingkat kepercayaan

$\mathrm{SD}=$ standar deviasi

$\mathrm{n}=$ jumlah pengulangan

\section{Validasi Metode}

\section{Uji Perolehan Kembali (recovery)}

Uji perolehan kembali atau recovery dilakukan dengan metode adisi (penambahan baku). Dalam metode adisi dengan menambahkan sejumlah larutan standar dengan konsentrasi tertentu pada sampel yang diperiksa, lalu dianalisis.

Menurut Harmita (2004), persen perolehan kembali dapat dihitung dengan rumus di bawah ini:

Persen Perolehan Kembali

$\%=\frac{C_{F-} C_{A}}{C_{A}^{*}} \times 100 \%$

Keterangan :

$\mathrm{C}_{\mathrm{A}}=$ Kadar logam dalam sampel sebelum penambahan baku

$\mathrm{C}_{\mathrm{F}}=$ Kadar logam dalam sampel setelah penambahan baku

$\mathrm{C}^{*}{ }_{A}=$ Kadar larutan baku yang ditambahkan 


\begin{tabular}{|c|c|c|}
\hline JURNAL PENELITIAN FARMASI HERBAL & VOL. 1 NO. 2 & $\begin{array}{c}\text { EDITION: NOVEMBER 2018 - } \\
\text { APRIL 2019 }\end{array}$ \\
\hline & http://ejournal.delihusada.ac.id/index.php/JPFH & \\
\hline RECEIVED: 17 FEBRUARI 2019 & REVISED: 20 MARET 2019 & ACCEPTED: 26 APRIL 2019
\end{tabular}

\section{Uji Keseksamaan (Presisi)}

Uji keseksamaan atau presisi diukur sebagai simpangan baku relatif atau koefisien variasi.. Nilai simpangan baku relatif yang dapat memenuhi syarat menunjukkan adanya keseksamaan metode yang dilakukan (Harmita, 2004).

Menurut Harmita (2004), rumus untuk menghitung simpangan baku relative adalah:

$$
R S D=\frac{S D}{\bar{x}} \times 100 \%
$$

Keterangan:

$\bar{x}$ : Kadar rata-rata sampel

SD : Standard Deviation

RSD : Relative Standard Deviation

\section{Penentuan Batas Deteksi (Limit of Detection) dan Batas Kuantitasi (Limit of Quantitation)}

Menurut Harmita (2004), danRohman (2007) batas deteksi dan batas kuantitasi ini dapat dihitung dengan rumus sebagai berikut:

$$
\begin{aligned}
& \text { Simpangan Baku }=\sqrt{\frac{\sum(\mathrm{Y}-\mathrm{Y})^{2}}{\mathrm{n}-2}} \\
& \text { Batas Deteksi (LOD) }=\frac{3 \times S E}{s l o p \theta} \\
& \text { Batas Kuantitasi (LOQ) }=\frac{10 \times S E}{s l o p \theta}
\end{aligned}
$$

\section{HASIL DAN PEMBAHASAN Kurva Kalibrasi Kalsium}

Sampel yang digunakan dalam penetapan kadar kalsium adalah jambu, jahe, dan pala. Masing-masing sampel dalam bentuk segar, manisan basah, dan manisan kering. Penetapan kadar kalsium dilakukan secara spektrofotometri serapan atom.

$$
Y=0,036592 X+0,00584
$$

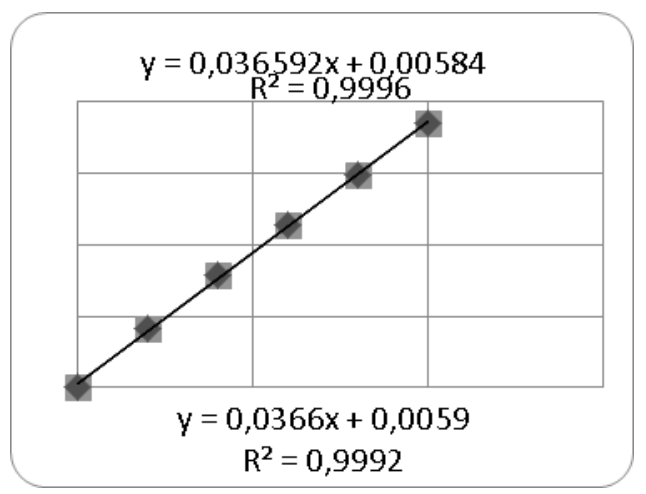

Gambar 1. Kurva Kalibrasi Larutan Standar Kalsium

Berdasarkan kurva di atas diperoleh hubungan yang linear antara konsentrasi dengan serapan, dengan koefisien korelasi (r) kalsium 0,9996,. Nilai $r \geq 0,97$ menunjukkan adanya korelasi linier yang menyatakan adanya hubungan antara $X$ (konsentrasi) dan $Y$ (Absorbansi) (Ermer dan Miller, 2005).

\section{Hasil Analisis Kadar Kalsium}

Munurut Memet dan Yusuf (2004) agar manisan buah yang dihasilkan renyah, sebelumnya harus direndam dalam larutan kapur. Kapur dapat membetuk tekstur buah yang diolah menjadikuat sehingga manisan terasa lebih renyah. Perubahan ini disebabkan adanya senyawa kalsium dalam kapur yang berpenetrasi ke dalam jaringan buah.

Hasil Pengukuran Kadar Kaslium (mg/100g) pada jambu segar $7,7105 \pm 0,1224$; manisan jambu basah 13,7787 $\pm 0,4626$; manisan jambu kering 160,9401 $\pm 0,4223$; jahe segar $14,5232+0,1170$; manisan jahe basah $22,8345 \pm 1,0315 ;$ manisan jahe kering $176,0465 \pm 1,0458$; pala segar 38,8834 $\pm 0,6996 ;$ manisan pala basah $56,8889 \pm 0,4702$; manisan pala kering $120,4426 \pm 0,8687$.

Akibatnya, struktur jaringan buah menjadi lebih kompak berkat adanya ikatan baru antara kalsium dan jaringan dalam buah. Terdapat interaksi antara lama perendaman dengan konsentrasi $\mathrm{Ca}(\mathrm{OH})_{2}$ terhadap kadar 


\begin{tabular}{|c|c|c|}
\hline JURNAL PENELITIAN FARMASI HERBAL & VOL. 1 NO. 2 & $\begin{array}{c}\text { EDITION: NOVEMBER } 2018- \\
\text { APRIL } 2019\end{array}$ \\
\hline & http://ejournal.delihusada.ac.id/index.php/JPFH & \\
\hline
\end{tabular}

kalsium manisan kering pepaya. Semakin lama perendaman dan semakin tinggi konsentrasi $\mathrm{Ca}(\mathrm{OH})_{2}$, maka kadar $\mathrm{Ca}^{2+}$ manisan kering pepaya yang dihasilkan semakin tinggi. Peningkatan tersebut karena semakin banyaknya ion $\mathrm{Ca}^{2+}$ yang masuk dalam jaringan buah melalui proses difusi, yaitu larutan akan bergerak dari konsentrasi tinggi ke konsentrasi rendah, sehingga kadar $\mathrm{Ca}^{2+}$ meningkat (Latifah, dkk., 2015).

Dengan demikian dapat dikatakan bahwa peningkatan kadar kalsium terjadi karena pada saat perendaman air kapur $\left(\mathrm{Ca}(\mathrm{OH})_{2}\right)$ kalsium berpenetrasi ke dalam jaringan buah sehingga meningkatkan kadar kalsium dalam buah tersebut.

\section{Uji Akurasi}

Persen perolehan kembali (recovery) kadar mineral kalsium, natrium dan tembaga dalam sampel dapat dilihat pada Tabel 2.

Tabel 1. Persen perolehan kembali (recovery) kadar kalsium

\begin{tabular}{|l|l|l|}
\hline Mineral & $\begin{array}{l}\text { Rata-rata } \\
\text { recovery } \\
(\%)\end{array}$ & $\begin{array}{l}\text { Syarat } \\
\text { Rentang } \\
\text { persen } \\
\text { recovery }(\%)\end{array}$ \\
\hline Kalsium & 105,6201 & $80-120$ \\
\hline
\end{tabular}

Berdasarkan Tabel 2 di atas, dapat dilihat bahwa hasil rata-rata uji perolehan kembali (recovery) kalsium adalah 105,6201\%. Persen recovery tersebut menunjukkan kecermatan kerja yang memuaskan pada saat pemeriksaan kadar kalsium dalam sampel. Hasil uji perolehan kembali (recovery) ini memenuhi syarat akurasi yang telah ditetapkan, jika rata-rata hasil perolehan kembali (recovery) berada pada rentang 80-120\% (Ermer dan Miller, 2005). Nilai simpangan baku dan simpangan baku relatif kalsium dalam sampel dapat dilihat pada Tabel 3.
Tabel 2. Nilai simpangan baku dan simpangan baku relatif kalsium

\begin{tabular}{|c|c|c|}
\hline Mineral & $\begin{array}{l}\text { Simpangan } \\
\text { Baku }\end{array}$ & $\begin{array}{c}\text { Simpangan } \\
\text { Baku Relatif }\end{array}$ \\
\hline Kalsium & 5,9232 & $5,60 \%$ \\
\hline
\end{tabular}

Berdasarkan Tabel 2 diatas dapat dilihat nilai simpangan baku (SD) dan simpangan baku relatif untuk masing-masing mineral. Nilai simpangan baku relatif (RSD) untuk analit dengan kadar part per million (ppm) adalah tidak lebih dari dari $16 \%$.Dari hasil yang diperoleh menunjukkan bahwa metode yang dilakukan memiliki presisi yang baik (Harmita, 2004).

Batas Deteksi (Limit of Detection) dan Batas Kuantitasi (Limit of Quantitation) Berdasarkan data kurva kalibrasi kalsium, natrium dan tembaga diperoleh batas deteksi dan batas kuantitasi kalsium yang dapat dilihat pada Tabel 3.

Tabel 3. Batas deteksi dan batas kuantitasi

\begin{tabular}{|l|c|c|}
\multicolumn{3}{c}{ kalsium } \\
& $\begin{array}{c}\text { LOD } \\
(\mu \mathrm{g} / \mathrm{ml})\end{array}$ & $\begin{array}{c}\text { LOQ } \\
(\mu \mathrm{g} / \mathrm{ml})\end{array}$ \\
\hline Kalsium & 0,36129 & 1,20430 \\
\hline
\end{tabular}

Dari hasil perhitungan diperoleh batas deteksi untuk pengukuran kalsium 0,3621 $\mu \mathrm{g} / \mathrm{mL}$, sedangkan batas kuantitasinya sebesar 1,20430 $\mu \mathrm{g} / \mathrm{mL}$. Dari hasil perhitungan dapat dilihat bahwa semua hasil yang diperoleh pada pengukuran sampel berada di atas batas deteksi dan batas kuantitasi.

\section{KESIMPULAN}

a. Kadar kalsium pada sampel segar jambu biji, jahe dan pala berturut-turut setiap masing-masing sampel sebagai berikut $(7,7105 \pm 0,1224) \mathrm{mg} / 100 \mathrm{~g},(14,5232 \pm$ $0,117) \mathrm{mg} / 100 \mathrm{~g}$ dan $(38,8834 \pm 0,6996)$ $\mathrm{mg} / 100 \mathrm{~g}$. Pada manisan basah jambu biji, jahe dan pala sebesar $(13,7787 \pm$ $0,4123) \mathrm{mg} / 100 \mathrm{~g},(22,8345 \pm 1,0315)$ $\mathrm{mg} / 100 \mathrm{~g}$ dan $(56,8889 \pm 0,4702)$ 


\begin{tabular}{|c|c|c|c|}
\hline \multirow[t]{2}{*}{ JURNAL PENELITIAN FARMASI HERBAL } & \multicolumn{2}{|c|}{ VOL. 1 NO. 2} & $\begin{array}{l}\text { EDITION: NOVEMBER } 2018- \\
\text { APRIL } 2019\end{array}$ \\
\hline & \multicolumn{2}{|c|}{ http://ejournal.delihusada.ac.id/index.php/JPFH } & \\
\hline RECEIVED: 17 FEBRUARI 2019 & \multicolumn{2}{|c|}{ REVISED: 20 MARET 2019} & ACCEPTED: 26 APRIL 2019 \\
\hline \multicolumn{2}{|c|}{$\begin{array}{l}\text { mg/100 g. Sedangkan pada manisan } \\
\text { kering segar jambu biji, jahe dan pala } \\
\text { sebesar }(160,9401 \pm 0,4626) \mathrm{mg} / 100 \mathrm{~g}, \\
(176,0465 \pm 1,0458) \mathrm{mg} / 100 \mathrm{~g} \text { dan } \\
(120,4426 \pm 0,8687) \mathrm{mg} / 100 \mathrm{~g} . \\
\text { b. Kadar kalsium yang terkandung dalam } \\
\text { sampel segar jambu biji, jahe dan pala } \\
\text { dan olahannya sebagai manisan basah, } \\
\text { dan manisan kering memiliki kadar yang } \\
\text { berbeda. }\end{array}$} & $\begin{array}{l}\text { Pada N } \\
\text { Rekapanc } \\
\text { Program } \\
\text { UPN. } \\
\text { Winarno, F.G. ( } \\
\text { Gizi. Jakı } \\
\text { Utama. H }\end{array}$ & $\begin{array}{l}\text { isan Pepaya". Jurnal } \\
\text { Vol.9, No. 1. Surabaya: } \\
\text { di Teknologi Pangan, FTI } \\
\text { 4). Kimia Pangan Dan } \\
\text { PT. Gramedia Pustaka } \\
\text { 154-155 }\end{array}$ \\
\hline
\end{tabular}

\section{DAFTAR PUSTAKA}

Ayu dan Rini. (2012). Membuat Manisan Buah. Cetakan Pertama. Jakarta: Pustaka Mina. Hal. 9-10

Ditjen POM. (1979). Farmakope Indonesia. Edisi Ketiga. Jakarta: Departemen Kesehatan RI. Hal. 692

Ditjen POM. (1995). Farmakope Indonesia. Edisi Keempat. Jakarta: Departemen Kesehatan RI. Hal. 1126, 1213

Ermer, J., and McB. Miler, J.H. (2005). Method Validation in Pharmaceutical Analysis. Weinheim: Wiley-Vch Verlag GmbH \& Co. KGaA. Hal. 171.

Fatah, M.A., dan Bachtiar, Y. (2004). Membuat Aneka Manisan Buah. Cetakan Pertama. Jakarta: AgroMedia Pustaka. Hal. 6, 9-10, 2324

Harmita. (2004). Petunjuk Pelaksanaan Validasi Metode dan Cara Perhitungannya. Review Artikel. Majalah Ilmu Kefarmasian. 1(3). 117 $-119,12-122,127-130$.

Rohman, A. (2007). Kimia Farmasi Analisis. Cetakan I.Yogyakarta: Pustaka Pelajar. Hal. 298, 305 - 306, 310 312

Schuette, S.A., dan Linkswiler, H.M. (1988). PengetahuanGizi MutakhirMineralKalsium. Jakarta: PT. Gramedia. Hal. 3

Sudjana. (2005). Metode Statistika. Edisi Keenam. Bandung: Tarsito. Hal. 93, 168, 239.

S. Basuki, E.K., Latifah, dan Sari, R.N. (2015). "Kajian Lama Perendaman Dan Konsentrasi Kalsium Hidroksida 